\title{
Proto-Oncogene c-Fos
}

National Cancer Institute

\section{Source}

National Cancer Institute. Proto-Oncogene c-Fos. NCI Thesaurus. Code C17438.

Proto-oncogene c-Fos (380 aa, $41 \mathrm{kDa}$ ) is encoded by the human FOS gene. This

protein is involved in transcriptional regulation, DNA binding and signal transduction. 